\section{THE ROYAL SOCIETY OF MEDICINE.}

OPENING OF THE NEW BUILdiNgS BY THE KING.

THE King, who was accompanied by the Queen, formally opened the new building of the Royal Society of Medicine at No. 1, Wimpole-street, on Tuesday afternoon, May 21st, in fine weather. A guard of honour, under the command of Major H. H. Tooth, was mounted by a medical contingent of the University of London Officers' Training Corps. The Royal party reached the main entrance of the building punctually at a quarter to fonr.

A large and distinguished assembly awaited the arrival of Their Majesties, who were received on alighting from their carriage by the President, Sir Henry Morris, the honorary secretaries, Dr. Arthur Latham and Mr. H. S. Pendlebury, and the secretary, Mr. J. Y. W. MacAlister. The members of the Council and of the Building Committee waited on either side of the entrance hall. As the Queen entered the building she was presented with a bouquet by Mrs. Arthur Latham. Their Majesties proceeded to the Robert Barnes Hall, where the President read the following address :-

To the King's and the Queen's Most Excellent Majestues.

May IT PLEASE Your Ma.Jestues,

We, the President, Conncil, and Fellows of the Royal Society of Medicine, desire to convey to Yuur Majesties, with our loyal duty, our attachment and devotion to Four Persons and to the Throne.

We take this opportunity to express our grateful appreciation of the deep interest which Tour Majesties invariably evince in all that concerns the well-being of Four subjects, as well as in the progress of our profession, whose vocation it is not only to preserve the individual by curing disease, but to improve the health of the nation by promoting hygiene and preventing illness. Our society was founded in the year 1805, but greater stability and effect were given to its designs by the Charter granted in 1834 by the special grace of His Majesty King William IV., who thereby declared himselt, "and his successors if they shall think fit," the Patron of the society.

It is our pride and privilege to record that each of the illustrious Successors of King William IV. has so thought fit, and that our greatly beloved, and never to be forgotten late Sovereigns, Her Majesty Queen Tictoria, and His Majesty King Edward TII. have been, and now your own excellent Majesty is our Patron.

By a Supplementary Charter graciously granted in the year 1907 by Your Majesty's august Father, the society was empowered to enrol as Fellows the members of several younger societies having allied objects; the scope of the society was enlarged; its name was changed from "The Royal Medical and Chirurgical Society of London" to "The Royal Society of Medicine" ; and it was specifically ordained that female as well as male persons might be elected Fellows and appointed to offices of the societr.

Thus the Rofal Society of Medicine now forms a large corporation, embracing within its fold the most important medical societies in the country, and having for its object the improvement of the art and science of Medicine in all its branches by means of debate, collaboration, and research.

Your Majesties who at all times show very active sympathy in the work of the great hospitals and similar institutions, and in every thing that tends to alleviate sickness and relieve suffering, take also, as we are well aware, a keen and enlightened interest in every advancement of medical knowledge directed to the furtherance of these humane ends. Such progress is the single purpose of this society.

To have been distinguished by the gracious farour of Your Majesties on this auspicious occasion has given inexpressible pleasure to all concerned and is a recognition that reflects the brightest lustre upon the history of the society.

It is with these feelings of appreciation and gratitude that we very earnestly thank Your Majesties for the great honour you have conferred upon us, and upon the profession at large, by Your presence here to-day.

HENRY MORRIS,

President.

WILLIAM S. CHURCH,

Francis H Champanys,

Hon. Treasurers.

R. J. GODLEE,

Norman MOORE,

ARTHUR LATHAM

Hon. Librarians.

Herbert S. Pendlebury, $\}$ Hon. Secretaries. J. Y. W. MAdAlister, Secretary.
HIS MAJESTY replied:-

I thank you on behalf of the Queen and myself for the loyal and dutiful address of the Ruyal Society of Medicine. It gives me great pleasure to open the fine building which will henceforth be the home of the society, and which will provide adequately for the increase in your membership and for the extension of your duties since a new and enlarged charter was granted to you by my father, King Edward.

The importance of the society's work is now universally recognised, and it is a matter of satisfaction that the needs of the society have been so generously provided for, and that its varied functions can now be carried on unhampered by lack of space. The health and well-being of the community are safeguarded by the energies of the medical profession. We look to you to fight sickness and disease, and we claim from you an untiring vigilance in this contest, and unceasing efforts to find, by the investigation of the laws of nature, new means of combating these enemies. Medical science has revealed by experiment and trained observation new securities for life and health during recent years, and none can doubt that the improved public health is mainly due to the discoveries made by the medical profession in this and other countries, to the guidance given by that profession to the civil authorities, and to the sanitary precautions against the spread of disease which they have enforced. It gives us the greatest satisfaction to assist in any way the interests of your noble calling, and the Queen and $I$ will ever watch the progress of your society with sympathy and hearty goodwill.

It only remains for me to declare this new building opened, which I do with the greatest satisfaction and pleasure.

Their Majesties next proceeded to the basement, the King having expressed a special desire to examine the book-store. Here a large proportion of the books are kept on adjustable iron shelves which have been specially designed to secure economy of space. The honorary librarians, Mr. Rickman J. Godlee and Dr. Norman Moore, conducted Their Majesties through this department. Returning to the first floor the King and Queen entered the library.

The Library.

This has already been described in our columns ride THE L.1XCET, Tol. I., 1911, p. 758), and it will be sufficient to remind our readers that the room occupies the whole length of the building and is $110 \mathrm{ft}$. long, $28 \mathrm{ft}$. wide, and $19 \mathrm{ft}$. high. The books housed in the library number 100,000 . It is a curious coincidence that this number almost exactly corresponds with the number of pounds sterling which the society has spent in iuvestigating medical subjects and in publishing and circulating medical literature. This library, which has been removed from its old quarters, is one of the finest collections of medical literature in the world, and the system of distribution bas been so perfected that its utility reaches throughout the ends of the British Empire. In addition to the convenient table lamps referred to below, the ceiling lights are so arranged that light is reflected upward and then back by the wide expanse of white ceiling throughout the whole room.

In the library the following were presented to the King and Queen by the President:-Sir William S. Church, Sir Francis H. Champneys, Mr. J. Warrington Haward, Dr. Frederick Taylor, Mr. Clinton T. Dent, Dr. Amand Routh, Dr. R. T. Hewlett, Dr. Theodore Thomson, Mr. H. Lloyd Williams, Sir William Osler, Sir Malcolm Morris, Dr. George H. Thompson, Dr. F. W. Mott, Dr. StClair Thomson, Dr. Wr. J. McCardie, Mr. Richard Gill, Dr. William Milligan, Mr. Arthur H. Cheatle, Dr. G. A. Sutberland, Mr. A D. Reid, Mr. W. Deane Butcher, Dr. W. E Dixon, Dr. R. A. Gibbons, Dr. W. P. Herringham, Mr. R. Clement Lucas, Mr. D'Arcy Power, Dr. H. D. Rolleston, Mr. Charters J. Symonds, and Mr. E. F. White. The following rnembers of the Building Committee who are not on the Council were then presented: Dr, Herbert $R$. Spencer, Dr. C. Theodore Williams, Dr. Leonard L. B. Williams; and also the architect, Mr. John Belcher, the representative of the lady Fellows, Dr. Mary Scharlieb, and the editor of the society's Transactions and Journal, Dr. John Nachbar.

Their Majesties were then conducted round the library. One of the first things which attracted the attention of the King was a novel electric-lighting arrangement for writing tables, the invention of the secretary. Having realised the inconvenience of the flexible cord 
which has hitherto been used for supplying the electric current to table-lamps, Mr. MacAlister : devised a small apparatus which does away with the old form of standardlamp attachment. It consists of a socket in the floor connected with the source of electric supply, and a plug in the leg of the table which fits into this socket. The plug is kept in position by a spring, the resiliency of which is easily overcome by the weight of the table. A model of this attachment was accepted by the King. Their Majesties then examined the old roll of the Royal Medical and Chirurgical Society, the parent of the new organisation, and showed great interest in the names of the eminent medical men therein inscribed. A special page was inserted in the obligation Book for the Royal signatures, inscribed as follows:-

Royal Society of Medicine. Founded 1805, Incorporated by Royal Charter 1834, Supplementary Charter granted 1907. Opening of the His Majesty the King, Patron of the Society, accompanied by Her Majesty the Queen.

Subsequently Their Majesties were presented with copies of the history of the Society, and on leaving the library they were conducted to the second floor of the building. After passing through and inspecting the various committeerooms they proceeded to the Fellows' tea-room.

Those who took tea with Their Majesties included Sir Henry Morris, Sir William and Lady Church, Sir Francis and Lady Champneys, Mr. Rickman J. Godlee, Dr. and Mrs. Norman Moore, Dr. and Mrs. Arthur Latbam, Mr. H. S. Pendlebury, Mr. J. Y. W. MacAlister, Sir William and Lady Osler, Mr. Pierpont Morgan, the Lord Mayor and the Lady Mayoress, the Mayor and Mayoress of Marylebone, Sir Richard Douglas Powell, Sir James and Lady Reid, Sir Havelock and Lady Charles, Lord and Lady Strathcona, Sir Thomas and Lady Barlow, and Sir Francis Laking.

Shortly after 5 o'clock Their Majesties took leave of the Council, the President, and secretaries, who accompanied them to their carriage; but previous to their departure the King inspected the guard of honour. The newly formed band of this corps gave during the proceedings a programme of music.

It is interesting to note that the society has enjoyed Royal patronage since its incorporation in 1834. The society was founded under the name of the Medical and Chirurgical Society of London in 1805, and in 1834 King William IV. granted the society a Royal Charter and became its patron. On his death Queen Victoria became patron and signed the roll, and King Edward VII. as Prince of Wales presided over committees of the society at its house in Hanover-square, and upon his accession became patron and signed the roll. In 1905 as the Prince of Wales our present King was electea a Fellow of the society and attended the centenary dinner, and on his accession became patron.

Tuesday's ceremony was in every way a great success, and the arrangements for the Royal visit were admirably planned and carried out. The list of donations to the new building fund will be found in an early part of the zdver tisement pages of THE LANCET.

The Conetrazione.

On Wednesday evening, May 22nd, the President of the Royal Society of Medicine, Sir HENRY MornIs, entertained a large company at a conversazione in the sccicty's new house, to celebrate the Royal opening of the preceding day. The guests were received by the President in the Library, where a musical programme was provided by the string band of the Tniversity of London Officers' Training Corrs, under the direction of Mr. G. K. Roberts. An entertainment was also given in the Robert Barnes Hall, and during the evening the visitors had an opportunity of inspecting and admiring the many attractive features of the new bailding.

Her Majesty Queen Alexandra has giren her patronage to the carden lite to be held at Devonshire House on June 14th in aid of the National League for Physical Education and Imorovement.

THe anmual dinner of the West London Postgraduate College and Past ard Present members of the West London Fospital staff will be held at the Balmoral Rooms, Trocadéro Restaurant, Piccadilly-circus, on Tuesday, June 11 th, at 7.15 for 7.45 P. .1., under the chairmanship of Dr. Arthur Saunders.

\section{THE NATIONAL INSURANCE ACT.}

\author{
ABERDEEN PRACTITIONERS AND THE ACT.
}

UNDER the auspices of the British Medical Association a meeting of the Aberdeen practitioners was held on May 13th, when the following report was submitted and alopted provisionally, pending the final decision of the Association as a whole :-

The Provisional Medical Committee (Aberdeen Division), in submitting a report, desire to premise that the recommendations therein contained are made whout prejudice to the question (at present under consideration of the committee) of whether or not, in working the
Insurance Act, the principle of contract work should be abolished and Insurance Act, the principle of contract work
that of payment for work done substituted.

Your committee, subject to the above qualification, recommend the adoption of the principle of a minimum capitation fee of $8 s .6 d$. for medical attendance without medicine, extra payments to be made for special work. In considering this matter, your committee has reference to the report made last year by the Contract Practice Committee of the Aberdeen Medico-Chirurgical Society. This report, embracing 25 practices with 56 clubs, and a total club membership of at least 12,000 , showed that the average fee per visit or consultation worked out at $10 \mathrm{~d}$. to $1 s$. without medicine, and $8 d$, to $10 d$. with medicine, but the number of visits or consultations was in most cases only an approximate calculation.

Your committee has now considered the returns, accurately made out for the whole year 1911, of another local practice, which includes five societies with a total membership of 1856 . In this practice the payment per visit or consultation. when patients had to buy their own medicine, worked out at $11 d$., and when they were supplied with each patient was visited by or consulted the doctor $4 \cdot 25$ times per annum.

Your committee, in considering the ways in which the Insurance Act would still further depreciate the very low present payments of points:-

1. Hitherto all Friendly Society members have been health $y$ and only, as a rule, eligible for membership under 40 years of age. Under the Insurance Act all lives, including the unbealthy and chronic invalids, would have to be treated, and all under 65 years of age would be eligible.

2. Friendly Societies have bitherto been recruited from classes earning a fair living wage, and hence able, by means of wholesome food, fairly comfortable dwellings, Kc., to keep themselves in fair health. Under the Insurance Act the very poorest will be included-people who,
from inability, through low wages, \&c., to beep themselves in satisfrom inability, through low wages, \&c., to beep themselves in satis-
factory condition, are more apt to contract ilness and require factory cond

3. At present many members of societies are members of more than one society or club; they are attended by one medical man, but the medical ofticer of their other lodge or lodges is paid their medical mediribution. Under the Act every individual on each practitioner's list will be that practitioner's actual patient.

4. In present Friendly Society practice much minor surgery and many accidents go to hospital for treatment; under the Act the
bospitals, in all likelihood, will decline to treat such insurance cases.

5. At present. when Friendly Society patients afford their own meilicines, the doctor has, in many cases, simply to advise the patient to continue the medictne for a considerable period; under the Act no medicine or repetition of is aill be obtainable by patients without medical prescription, and the practitioner's time will be much more occupied in ordering xeperitions of medicine (observe that when
medicines are not suppled the payment was found to be $11 d$., as against medicines are not supplied the pay
$6 d$. when medicines were supplied).

6. A poor class will be inchuded under the Act, who hitherto, from inability to pay for doctor or medicine, have only sought treatment in serious illness; under the Act this class, when it realises that medieal attendance and medicine are gratuitous, will, very properly, develop the halit of calling upon, or sencling for, the doetor on the slightest disabilit ${ }^{4}$, and will prove as realy to call upon his services and as exacting as any wealthy private patient.

7. Hitherto medical men have been induced to take Friendly Societies at their low ligures in the hope of thus securing members' families as private patients. Under the Act this inducement will not hold good. The insured individual will select from the panel of practitioners the medical man who is alreacty his own and his family's doctor, and the be the families of the very poor elass.

8. Practitioners in Aberleen will find the Act to involve special hardship. The area of the city is wide, and no one district is so densely populated as to exclusively support a practice, with the result that practitioners have to go all over the area. It is not fair that men covering a large daily mileage inrolvins more time and running densely populated districts, such as Glasgow, Manchester, Birmingham and London, and making rounds of risits in closely arljoining streets of one district.

In the course of discussion it was pointed out that the profession will never contemplate depriving any class, least of all the poorest, of proper medical attendance, and that failing an agreement ander the Act, they will themselves make their arrangements for this purpose. 